\title{
Insurance for Msme Development in Indian Context
}

\author{
Ashim Kumar Das, Abhijit Chakraborty
}

\begin{abstract}
MSME development is a much required function for the development of an economy. Insurance is very old business cum service that supports the commercial activities by owning the risk associated in exchange for premium. The objective of this paper is to find out whether any relationship exists between the insurance and development of MSMEs in Indian context. The study uses Ordinary Least Square method to draw the regression equation and Granger Causality test to check for causality between Non-life Insurance sector development and development of MSME. It was found that non-life insurance and MSME are highly positively correlated. Though there is no causal relationship between these two variables but insurance has a positively significant influence on the development of MSME. The finding of this study indicates the requirement of favorable policies to develop the Insurance market in order to promote MSME leading to economic growth.
\end{abstract}

Keywords-India, MSME Development, Non-Life Insurance

\section{INTRODUCTION}

Insurance is a contract in which the Insurer agrees to protect the Insured against the financial loss if occurred due to insured events, in exchange for a consideration called "Premium". Insurance has two broad segment- Life and Non-Life. Whereas, Non-Life insurance is a contract of indemnity, Life Insurance is not. In this study, we will focus on non-life insurance as its impacts the commercial activities more, compared to Life Insurance. It is recognized as a service that helps in reducing the level of risk and uncertainty, and as such expected to help promote commercial activities. The MSMEs are a key element in the development of every nation [1]. Studies fill the literature with the importance of small and medium enterprises (SME) as employment generators, innovators, factors in supply chain of large enterprises and important contributor to gross domestic product (GDP). MSME in India has got its momentum with the new Economic Polices initiative in 1991 with an opening of the market to global competition brought in a new set of challenges and opportunities. The changes in the technology became faster compelling the entrepreneurs to prioritise innovation. The recent moves by the Indian government like Start Up India, Mudra Loan, Din Dayal Upadhay Kaushal Yojana etc. has fuelled up the MSME activities to a great extent but yet there are lacunas which needs to be resolved.

Revised Manuscript Received on October 31, 2019.

* Correspondence Author

Abhijit Chakraborty, Department of Management Studies, National Institute of Technology, Silchar, Assam, India. amiabhijit@gmail.com

Ashim Kr. Das*, Department of Management Studies, National Institute of Technology, Silchar, Assam, India. ashimkdnits@gmail.com
Table 1. MSME Classification according to MSME Act 2006

\begin{tabular}{|l|l|l|}
\hline $\begin{array}{l}\text { Enterprise } \\
\text { (Type) }\end{array}$ & $\begin{array}{l}\text { Investment in } \\
\text { Plant \& } \\
\text { Machinery } \\
\text { (Manufacturing) }\end{array}$ & $\begin{array}{l}\text { Investment in } \\
\text { Equipment } \\
\text { (Service) }\end{array}$ \\
\hline Micro & Up to 25 lakh & Up to 10 lakh \\
\hline Small & $\begin{array}{l}\text { Above 25 lakh } \\
\text { upto 5 crore }\end{array}$ & $\begin{array}{l}\text { Above 10 lakh } \\
\text { upto 2 crore }\end{array}$ \\
\hline Medium & $\begin{array}{l}\text { Above 5 crore } \\
\text { upto 10 crore }\end{array}$ & $\begin{array}{l}\text { Above 2 crore } \\
\text { upto 5 crore }\end{array}$ \\
\hline
\end{tabular}

Micro Small and Medium Enterprises (MSME) plays a vital role in Indian economy by contributing more than $45 \%$ of the industrial output, $40 \%$ of total Indian export, 42 Million employment and it was also estimated that almost 1 million jobs are created every year. These SMEs may be entrepreneur ventures where the promoter invests his or her savings/borrowings to start a new venture.

The MSMEs are the best representatives of economic activities [21]. The development of MSME largely depends upon the availability of financial services, including insurance, which is a crucial element of sustainability of businesses in the long run. The insurance sector along with other financial sectors needs to work effectively so as to remove uncertainties from the operation of business.

The MSME sector could draw little attention from the insurance sector so far, as there are no customized products available in the market that suits the unique needs of the MSME sector. It needs a thorough understanding of the value chain of MSMEs and the challenges they face in their operation and sustaining, in order to design and develop appropriate customized products for this MSME sector. [1] Risk is inherent in our lives but, MSME are specially venerable to risks that threaten the dream venture that the entrepreneur has worked hard to build. As the stakes been so high, Insurance is a prudent way to limit liabilities in the event of damage to assets, property and business which is a key to survival for a small venture. According to FICCI - KPMG report only $10 \%$ of the employee of MSMEs have health insurance, only $0.1 \%$ of other core property risk covered like fire, marine etc. Most of them (MSMEs) lag behind Corporates on usage of safety practices. 
They run with huge risk of workplace related accidents besides flood, earthquake, electric short circuit etc. These risks have the potential to cripple their business.

Non-life Insurance majorly serves the need of enterprises. The business houses buy insurance to protect themselves against accidents, loss of life of key persons, lawsuits, fire, damage, burglary etc. But in Indian scenario, the insurance buying in non-life sector is not at par with the global standard. This may be due to - lack of awareness about the benefits of insurance product or the products available are not affordable. The lack of availability of insurance services for small and medium sector entrepreneurs fails to reduce the level of uncertainty and discourages people to take up new ventures, which effect the growth of the economy.

Chart 1: Growth of MSMEs and Employment Generation

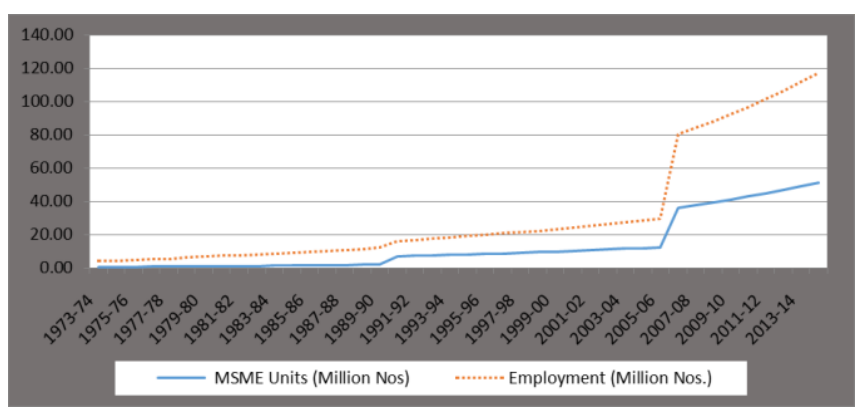

Source: MSME Annual Report compiled by author

\section{MSMES AND UNCERTAINTY}

The phenomenon of insurance started long back before Christ. The insurance coverage mainly started to protect the traders from perils of sea. Chinese merchants formulated devise to protect their cargo travelling through the sea from hurricanes, pirates etc. They used to spread the cargo among fleets so that if even a particular ship faces some calamity, the entire lot of goods are not damaged or wasted [24]. This was the first case of risk diversification and reduction. The modern day Insurance got its origin in Babylon where traders provde loans for a caravan. The amount of loans were paid back only when the goods arrived safely [6, 17, 31]. This exercise, called bottomry, was acknowledged in Hammurabi's code (ca. 2100 B.C.) and it is a clear evidence of existence of insurance in those days [29].

The human history thus evidences the challenges faced by traders due to uncertainty since inception of business. Entrepreneur always tried to devise ways to handle uncertainties with the help of instruments available to carry on their business activities. The uncertainties and risks involved in the business affairs have restricted many businesses to flourish and there are instances of great businesses falling down due to their failure to predict, realize and handle uncertainties resulting from change of business environment, customer demand, govt. regulations etc. But, risk \& uncertainties are an inherent element in business and those cannot be fully eliminated, instead they need to be managed. The introduction of Insurance might have happened as all the people are not risk averse. While some people try to avoid risk, there may be others interested to try the same. This gap between two types of risk-responsive people has been filled in by "Insurance". The risk-taking people coming forward to take the risk, which the risk-averse people want to shift from their shoulder, for a consideration called "Premium".
The modern day business environment possesses a lot many challenges. The global competition having profound impact on the domestic market brings around uncertainty in the continuation of MSMEs. From the point of inception and incubation till stability, uncertainties and risks hover around the newly started enterprises from different corners. These uncertainties paralyze the enthusiasm of the MSMEs owner manager.

The Prospect Theory forwarded by Kahneman and Tversky (1979) [10] suggests that the behavior of people changes with the change in circumstances. It says, that the attitude of individuals towards gains (risk averse) is different from the attitude towards losses (risk seeking). Baumol (2006) [40] advocates that the innovative entrepreneurs love to take risks. The risk loving people are those who have a preference for risk. These people take on risk, capitalize opportunities, create economic worth and thus adds to the production process of the economy.

In the absence of Insurance and its protection-against-uncertainties services, the MSMEs will be reluctant to undertake innovative steps and instead hang on existing business model to ensure certainty. This will subsequently lead to under-productivity of the business enterprises hampering economic growth $[35,36,40]$. MSME are at the centre of economic growth and they should be supported with supply of appropriate insurance products at reasonable price.

This paper tries to explore the link between Insurance and MSME in Indian context. The low penetration of Non-Life Insurance in India does not support the reduction of uncertainties and thus restricts the growth and sustainability of MSME.

\section{LITERATURE REVIEW}

There is dearth of research involving the relationship between insurance and MSME and the number of research in this area in India is even lower.

In the recent past the recognition of MSME as an engine for growth has enriched the bank of literatures involving studies in this area. The contribution of MSMEs to the development of an economy were established by many authors in their research work as they find this sector to support in areas of employment, innovation, feeder of large enterprises and growth of GDP [1].

The development of MSMEs can be viewed as development of economic activities and vice versa. Entrepreneurship also adds to the development of MSMEs. Many authors have used the terms - Entrepreneurs and MSMEs- interchangeably. In some cases, the MSMEs are the business houses whereas the Entrepreneurs are the owners who initiate, run and manage those MSMEs.

There a deep connection between uncertainty and Entrepreneurship as Harper $(2007,2008)[19,20]$ defined entrepreneurship as a process of problem solving in uncertain environments to earn profit.

Knight, Frank Hyneman (2012) [26] opined that entrepreneurs choose to operate in an environment that ensures reliability and stability. 
According to Knight, the entrepreneurs possess an ability to gauge the uncertainty associated with certain events and look institutions along with legal set up plays an important role in promoting or restricting Entrepreneurship and MSMEs in a nation. The institutional setting has an important role to play in terms of removing credit constraints (Banerjee and Newman, 1993) [5], the lowering regulatory complications (Johnson, McMillan, and Woodruff 2002) [23] and resolving the non-availability of credit to the MSMEs. Casson and Godley (2005) [7] quoted that owners need sufficient wealth in order to become entrepreneurs, which calls for the need of financial support in promotion of entrepreneurial activity leading to development of MSMEs.

Mel, McKenzie and Woodruff (2007) [27] in their paper supported that existence of proper insurance support can facilitate and promote access to credit.

The literature base on the relationship between insurance and MSME provides sufficient reasons to argue that productive activities gets encouraged by the existence of an efficient insurance market. UNCTAD in its conference in 1964 acknowledged that Insurance sector is a primary requirement of an economy to develop. The insurance industry does a very important job of capital accumulation by collecting regular premiums from the insurance buyers which is routed to long-term capital intensive projects considered as the pillars of sustained economic growth. The continuity in growth cycle is ensured by constant innovations and upliftment of the production mechanism which helps to retain and extend market share in the global competitive market place. The innovations gets in place with the promotion of MSMEs which can be supported in a better manner by availing the services of insurance.

\section{OBJECTIVE OF THE STUDY}

The study intended to analyse the relationship between Insurance and the development of MSMEs in India to establish the need to encourage non-life insurance sector in order to get a sustained growth of MSMEs. On the backdrop of the general assumption that Insurance sector helps promote business activity and thus encourage MSMEs in India by providing a wide range of services to protect them against risk and uncertainties. The objective of the study are as follows:

1) To identify the relationship between insurance sector and development of MSME in India.

2) To understand the degree of influence of Insurance sector growth on MSME Development in India.

\section{MEASUREMENT OF VARIABLES}

Two variables MSME and Non-Life Insurance are involved in this study. To represent the development in MSME, the number of MSMEs over the period of 1991 to 2015 was taken as a proxy. The data for same was extracted from Annual Reports from 2007-08 to 2017-18 issued by Ministry of Micro, Small and Medium Enterprises, Govt. of India and is available in their website www.msme.gov.in .

The measure the development of Non-life insurance sector, the non-life insurance penetration, that is, percentage of non-life insurance premium to the GDP over the period of 1991 to 2015 was taken as a proxy. The required data for the after the interest of all stakeholders. The economic

same was collected from Sigma Explorer published by Swiss Re.

\section{RESEARCH METHODOLOGY}

The nature of the data is Time Series covering a span of 1991 -2015 , i.e. 25 years. Correlation test was done to see the level of relationship between Development of MSME, measured by Number of MSMEs, and Development in Insurance Sector in India, measured by Non-Life Insurance Penetration. Insurance Penetration is a measure of percentage of Premiums to GDP. To measure the level and direction of influence of Insurance sector development on the development of MSME, regression equation was framed using Ordinary Least Square.

The conceptual model is :

$$
\text { MSMEs }=\mathrm{y}+\mathrm{b}_{1} . \text { INSPEN }
$$

Since we are studying only one factor and there will definitely be other factors influencing the development of MSME along with the factor under study, we reframe the above equation as follows:

$$
\text { MSMEs }=\mathrm{y}+\mathrm{b}_{1} . \text { INSPEN }+\mathrm{e}_{\mathrm{t}}
$$

The term " $\mathrm{e}_{\mathrm{t}}$ " Represents error term or residual and includes the influence of all other variables which also influence the development of MSME.

Post finalizing the empirical model, the causality of the variables were also checked using Granger Causality Test. This test is very popular and largely employed by the authors while testing the causality impact of one variable on the other. So, this test was selected for studying causality among the variables under study.

\section{DATA ANALYSIS AND INTERPRETATION}

To study the relationship between two or more variables it is a basic norm to check whether the variables are related to each other. If the variables are not related among themselves, then there is no point in assuming any liner relationship between them and drawing any regression equation involving those variables will simply be spurious. Therefore, the study checked the basic relationship between variables by using Test of Correlation between two variables. The correlation test revealed that the two variables are positively and significantly correlated. The development of MSME has a strong positive correlation with the development of non-life insurance sector. It was expected as the development in non-life insurance sector will result in more selling of those products which are designed to protect the entrepreneurs at small as well as large business sector from any uncertainty in the process of business.

TABle 2. CORRELATION TEST

\begin{tabular}{|ccc|}
\hline & INSPEN & MSMES \\
INSPEN & 1 & $0.86429912 \ldots$ \\
MSMES & $0.86429912 \ldots$ & 1 \\
\hline
\end{tabular}


Upon being confirmed about their association, present study headed towards testing the level of influence of Non-life Insurance Sector on the development of MSME. Ordinary Least Square Technique was used to draw the regression equation. The results are as follows:

\section{TABLE 3. REGRESSION TEST}

\begin{tabular}{|c|c|c|c|c|}
\hline \multicolumn{5}{|c|}{$\begin{array}{l}\text { Dependent Variable: MSMES } \\
\text { Method: Least Squares } \\
\text { Date: 09/07/19 Time: } 01: 26 \\
\text { Sample: } 19912015 \\
\text { Included observations: } 25 \\
\end{array}$} \\
\hline Variable & Coefficient & Std. Error & $\mathrm{t}$-Statistic & Prob. \\
\hline$\stackrel{\mathrm{C}}{\text { INSPEN }}$ & $\begin{array}{r}-712.7612 \\
1592.178\end{array}$ & $\begin{array}{l}111.6570 \\
193.2025\end{array}$ & $\begin{array}{r}-6.383490 \\
8.240980\end{array}$ & $\begin{array}{l}0.0000 \\
0.0000\end{array}$ \\
\hline $\begin{array}{l}\text { R-squared } \\
\text { Adjusted R-squared } \\
\text { S.E. of regression } \\
\text { Sum squared resid } \\
\text { Log likelihood } \\
\text { F-statistic } \\
\text { Prob(F-statistic) }\end{array}$ & $\begin{array}{r}0.747013 \\
0.736014 \\
79.75308 \\
146292.7 \\
-143.9046 \\
67.91376 \\
0.000000 \\
\end{array}$ & \multicolumn{2}{|c|}{$\begin{array}{l}\text { Mean dependent var } \\
\text { S.D. dependent var } \\
\text { Akaike info criterion } \\
\text { Schwarz criterion } \\
\text { Hannan-Quinn criter. } \\
\text { Durbin-Watson stat }\end{array}$} & $\begin{array}{l}197.9644 \\
155.2232 \\
11.67237 \\
11.76988 \\
11.69941 \\
0.661611\end{array}$ \\
\hline
\end{tabular}

The Model appears to be a good fit as the R-Squared value is 0.7470 indicating that $74 \%$ of the changes in MSME are explained by this model. The variable INSPEN, representing non-life Insurance penetration was found to be positively significant with a P-value of 0.0000 , indicating $99 \%$ level of confidence. That confirms the important role played by non-life insurance sector in the promotion of MSMEs in India.

\section{CAUSALITY TEST}

The variables used in the study showed positive correlation as well as it was found that non-life insurance is influencing MSMEs in a positively and significant manner. This motivates us to further explore the relationship in between these two variables in terms of causality. The Granger Causality test was employed to see the causality aspects

\begin{tabular}{|llll|}
\hline \multicolumn{4}{|c|}{ Pairwise Granger Causality Tests } \\
$\begin{array}{l}\text { Sample: } 19912015 \\
\text { Lags: } 2\end{array}$ & & & \\
\hline \hline Null Hypothesis: & Obs & F-Statistic & Prob. \\
\hline \hline MSMES does not Granger Cause INSPEN & 23 & 1.45551 & 0.2595 \\
INSPEN does not Granger Cause MSMES & & 0.45459 & 0.6418 \\
\hline \hline
\end{tabular}

The test revealed no causality between the variables. The null hypothesis of the test was that the variables does not granger cause each other. The corresponding probability value in both cases were more than .05 , and as such the Null Hypothesis cannot be rejected, instead, the study had to accept the alternative hypothesis which says that the there is no causality between the variables. This test reveals that both the variables are independent and does not granger cause each other.

\section{CONCLUSION}

Minimum support to MSME sector is essential to development and economic growth for every country like reduction of credit gap, access to finance, risk management system etc. The present study concludes that Non-Life Insurance sector is highly correlated with the development of
MSME and plays a positively significant role in influencing the development of MSME in India.

The Risk protection service of non-life Insurance is a vital contribution towards encouraging the entrepreneurs to take up new ventures, explore new market place, promote innovation, gear up production by increasing the marginal productivity of capital etc. The Entrepreneurs face a very challenging task of procuring financial support during their inception as well as during their incubation period. Finance is a difficult area to get access to and sometimes, it is available only through informal financial establishments. [1]. Many Entrepreneurs fail to stand up this tough phase leaded by financial crunch and die an early death, posing an adverse example for the others. The non-life Insurance can play a role of savior in these scenarios. The financial houses are reluctant to advance financial support to the fresh entrepreneurs due to their uncertainly of operation and successful continuance, as Entrepreneurs initially operate in a medium or small scale and are easily affected by changes in the business environment. But, if that uncertainty of continuance of their enterprises can be removed by using Insurance protection, the financial houses will not be reluctant to provide financial support. The entrepreneurs can transfer the insurable risks to the Insurer for a payment of premium and be free to concentrate of business operation. The insurance protection against uncertainties will enable them to qualify for financial assistance provided by banks and other financial houses. This will promote commercial activities setting favourable example for others to start enterprises. The economic growth will also be accelerated due to increase level of production and commercial transactions.

In sum, extending accessible insurance product to the MSMEs should be the prime agenda for creating a supportive environment. Insurance sector lacks in providing tailored and customized products for MSME segment and this scenario needs to be changed with proactive participation from the former. It is critical for the insurance industry to understand the requirement of the MSME customers and provide appropriate options so that they can cater the need of the segment and the people working in it, giving them the confidence to grow further. The Govt. of India should also come forward with policies and regulations to bring the MSMEs under the insurance umbrella providing them some basic protections either at free of cost or at most affordable rate which will encourage the promotion of MSMEs and entrepreneurship in India paving the road to economic development.

\section{REFERENCES}

1. A. Chatterjee \& W. Rodolfo, "Insurance for Micro, Small, and Medium-sized Enterprises," ADB Briefs, vol. 78, 2017, pp. 1-5.

2. A.K. Panigrahi, "Risk Management in Micro, Small and Medium Enterprises (MSMEs) in India: A Critical Appraisal," Asia Pacific Journal of Marketing \& Management Review, vol. 1 (4), 2012, pp. 59-72.

3. Aruwa and S.A.S, "Financing options for small and medium-scale enterprises in Nigeria," The Nigerian Journal of Accounting and Research, Department of Accounting, Ah-madu Bello University, Zaria, Vol.1 (2), 2004 , pp. 45-67.

4. A. Terungwa, "Risk Management and Insurance of Small and Medium Scale Enterprises (SMEs) in Nigeria", International Journal of Finance and Accounting, 1(1), 2012, pp. 8-17 
5. A. V. Banerjee \& F. N. Andrew, "Occupational Choice and the Process of Development,” Journal of Political Economy, vol. 101(2), 1993, pp. 274-98.

6. B. David, J. Wahl \& S. Rose, Executive's Guide to Solvency II. 1st ed. Wiley, 2010.

7. C. Mark \& G. Andrew, MSME and Historical Explanation in MSME in Theory and History of Cassis and Minoglou, 2005. Available: www.zotero://attachment/1667.

8. D. Ariyo, (2005). Small firms are the backbone of the Nigerian economy. Available: http://www.lib.umi.com.

9. D.B.E. Ekpenyong \& M. O. Nyong, "Small and medium-scale enterprises development In Nigeria," Seminar Paper on Economic Policy Research for Policy Design and Management In Nigeria, NCEMA/AEPC, Nigeria, April 1992, pp. 24-25.

10. D. Kahneman \& T. Amos, "Prospect Theory: An Analysis of Decision Under Risk," Econometrica - Journal of the Econometric Society, 1979, pp. 263-91.

11. D.M. Jadi, N.A. Manab, \& S.N. Ahmad, Insurance as a Risk Transfer Mechanism in Small and Medium Enterprises (SMEs), Conference Paper, August 2014.

12. D. Vander Nest, The Impact of Black Economic Empowerment on the Management of Small Companies in South Africa. Unpublished Master's Dissertation. Rand Afrikaans University, 2004.

13. E. Congregado, Measuring MSME: Building a Statistical System, Softcover reprint of hardcover 1st ed. 2008, Springer.

14. E.E. Inang G.E. Ukpong, A review of small-scale enterprises credit delivery strategies in Nigeria. Economic and Financial Review. CBN, 30(4), 1992.

15. E.I.K. Sule, Small scale industries in Nigeria: Concepts, appraisal of government policies and suggested solutions to identified problems, CBN Economic and Financial Review, 24 (4), 1986

16. E. Taymaz," "Are Small Firms Really Less Productive?," Smal Business Economics, vol. 25, 2005. Pp. 429-445

17. Franklin, James, The Science of Conjecture: Evidence and Probability before Pascal. 1st ed. The Johns Hopkins University Press, 2001.

18. G. Gregory, C. Harvive, \& H. Lee, Korean SMEs in the Wake of the Financial Crisis: Strategies, Constraints, and Performance in a Global Economy, Working Paper Series, University of Wollongong, 2002.

19. Harper, David, Foundations of Entrepreneurship and Economic Development, 1st ed. Routledge, 2007

20. Harper, David, "Towards a Theory of Entrepreneurial Teams." Journal of Business Venturing 23(6), 2008, pp.613-26.

21. Iversen, Jens, J. Rasmus \& M. M. Nicholaj, Defining and Measuring MSME Foundations and Trend, Now Publishers Inc., 2007.

22. J. F. Outreville, "The Economic Significance of Insurance Markets in Developing Countries, The Journal of Risk and Insurance, vol. 57(3) 1990, pp. 487-98.

23. Johnson, Simon, J. McMillan \& W. Christopher, Property Rights and Finance, National Bureau of Economic Research, Inc. NBER Working Papers, 2002 http://ideas.repec.org/p/nbr/nberwo/8852.html

24. J. Vaughan, Emmett \& T. M. Vaughan, Fundamentals of Risk and Insurance, 10th ed. Wiley, 2007

25. K. Chodokufa \& A. Chiliya,, "The Relationship between SMEs and Insurance providers in Nelson Mandela Metropolitan Area, South Africa," Mediterranean Journal of Social Sciences, vol. 5(14), 2014 pp. 84-95.

26. Knight \& H. Frank, Risk, Uncertainty and Profit. General Books LLC, 2012

27. Mel, S. De, D. McKenzie \& W. Christopher, Returns to Capital in Microenterprises: Evidence from a Field Experiment, World Bank Policy Research Working Paper No. 4230, 2007, SSRN eLibrary. Available:

http://papers.ssrn.com/sol3/papers.cfm?abstract id=985002

28. MSME at a glance, Govt of India, Ministry of Micro, Small and Medium Enterprises, 2016. (An ISO 9001:2008 Certified Organisation)

Available: www. http://msme.gov.in/mob/home.aspx

29. Niekerk \& J. P. Van, The Development of the Principles of Insurance Law: From 1500 to 1800, Hart Publishing, 1999.

30. P. Masci, A. Medici \& B.W. Barros, The Relationship Between Insurance and MSME in Brazil Concepts and Basic Data, Working Paper No. 1, 2007

31. Sachit, Insurance: History of Insurance, 2009 Insurance. Available: http://sachit-

insurance.blogspot.com/2009/02/history-of-insurance 16 .
32. Soto, H. De, The Other Path: The Economic Answer to Terrorism, 1s ed. Basic Books, 2002.

33. Swiss.Re, Press Release. Emerging Markets, 2004. Available: http://media.swissre.com/documents/pr_20041007_emerging_insuran ce_markets_en.pdf

34. V. Anic and V. Paus, The Croatian SME study: Best practice in Financing SMEs in SECI and CEI Countries: Final Report of UN/ECE Expert Meeting on Best practice in Financing SMEs. Geneva, 1998.

35. W. J. Baumol, "Entrepreneurship in Economic Theory." American Economic Review, vol. 58(2), 1968, pp. 64-71.

36. W. J. Baumol, "Entrepreneurship: Productive, Unproductive, and Destructive.” Journal of Political Economy, vol. 98(5), 1990, 893-921.

37. W. J. Baumol, "Entrepreneurship, Innovation and Growth: The David-Goliath Symbiosis." Journal of Entrepreneurial Finance and Business Ventures 7(2), 2002a, pp. 1- 10.

38. W. J. Baumol, The Free-Market Innovation Machine: Analyzing the Growth Miracle of Capitalism. Princeton University Press, 2002b, pp 23-45.

39. W. J. Baumol, "Education for Innovation: Entrepreneurial Breakthroughs Vs. Corporate Incremental Improvements", SSRN eLibrary, 2004.

Available: http://papers.ssrn.com/sol3/papers.cfm?

40. W. J. Baumol, "Return of the Invisible Men: The Microeconomic Value Theory of Inventors and Entrepreneurs." In Annual Meeting of the American Economic Association, Boston, 2006.

41. W. J. Baumol, The Microtheory of Innovative Entrepreneurship, Princeton University Press, 2010.

42. World Bank, Private sector development in low income countries, Washington, D.C, 1995

\section{AUTHORS PROFILE}

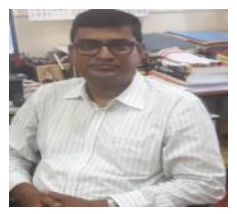

Dr. Ashim Kr. Das is working as Assistant Professor in the Department of Management Studies, National Institute of Technology, Silchar (An Institute of National Importance). He is an M.Com, M.Phil \& Ph.D. in Accounting. He has a total academic experience of more than 15 years. Mr. Das has more than 20 publications in reputed national and international peer reviewed journals published by Elsevier, Sage, Emerald etc. and indexed by Scopus, ABDC, SSCI etc. His area of focus is Entrepreneurship, SME, Tea Industry in North East India, Financial Accounting and General Management.

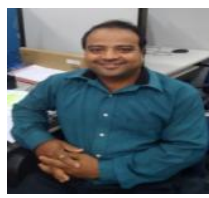

Abhijit Chakraborty is a Senior Research Fellow pursuing his Ph.D. program in the Department of Management Studies, NIT Silchar. His research area is Insurance. Mr. Chakraborty has done MBA with dual specialization in Marketing and Finance and M.Com in International Business. He is a fellow of the Insurance Institute of India. He has a corporate experience of more than 11 years in Banking and Insurance Industry. He has several publications in reputed national and international peer reviewed journals from Emerald, Sage etc. His research area includes insurance, entrepreneurship, MSME, ethical behavior etc. He is a Life Member in Insurance Institute of India. 